\title{
Novel recombinant immunotoxin of EGFR specific nanobody fused with cucurmosin, construction and antitumor efficiency in vitro
}

\author{
Cuimin Deng ${ }^{1, *}$, Jiani Xiong ${ }^{2, *}$, Xiaofan Gu ${ }^{1}$, Xiaoying Chen ${ }^{3}$, Shuifa Wu ${ }^{4}$, Zhe Wang ${ }^{1}$, \\ Duanduan Wang ${ }^{5}$, Jinjin Tu${ }^{1}$, Jieming $X_{i e^{1}}$ \\ ${ }^{1}$ Department of Pharmacology, Fujian Medical University, Fuzhou, Fujian, China \\ ${ }^{2}$ Department of Oncology, Fujian Medical University Union Hospital, Fuzhou, Fujian, China \\ ${ }^{3}$ Department of Experimental Teaching Center of Basic Medical Science, Fujian Medical University, Fuzhou, Fujian, China \\ ${ }^{4}$ Department of Pharmacology, The 180th Hospital of PLA, Quanzhou, Fujian, China \\ ${ }^{5}$ Department of Breast Surgery, Fujian Medical University Union Hospital, Fuzhou, Fujian, China \\ *These authors contributed equally to this work
}

Correspondence to: Jieming Xie, email: jmxie@mail.fjmu.edu.cn

Keywords: immunotoxins, nanobody, EGFR, cucurmosin

Received: November 16, $2016 \quad$ Accepted: March 24, $2017 \quad$ Published: April 07, 2017

Copyright: Cuimin Deng et al. This is an open-access article distributed under the terms of the Creative Commons Attribution License 3.0 (CC BY 3.0), which permits unrestricted use, distribution, and reproduction in any medium, provided the original author and source are credited.

\section{ABSTRACT}

Epidermal growth factor receptor (EGFR) overexpression is related to the increased aggressiveness, metastases, and poor prognosis in various cancers. In this study, we successfully constructed a new EGFR nanobody-based immunotoxin rE/CUS containing cucurmosin (CUS), The immunotoxin was expressed by prokaryotic system and we obtained a yield of $5 \mathrm{mg}$ protein per liter expression medium. The percentage of it's binding ability totumor cell lines A549, HepG2, SW116, which highly expressed EGFR was $55.6 \%, 79.6 \%$ and $97.1 \%$, respectively, but SW620 was only $4.45 \%$. rE/ CUS has the ability to bind A549, HepG2, SW116 cells specifically, and the antigen binding capability was not affected because of extra part of CUS component. The rE/ CUS significantly inhibited the cell viability against EGFR over expression tumor cell lines in a dose-and time-dependent manner. Moreover, $\mathrm{rE} / \mathrm{CUS}$ also induced apoptosis of HepG2 and A549 mightily. Our results demonstrate that rE/CUS is a potential therapeutic strategy for treating EGFR-positive solid tumors.

\section{INTRODUCTION}

In 2012, approximately 14 million new cancer cases were recorded and almost 8.2 million people died from cancer all around the world. Malignant tumor has become one of the common causes of death in the US, and accounted for nearly 1 of every 4 deaths [1]. Those most fatal one are epithelial cells derived from lungs, liver, breasts, prostate, and stomach [2]. Although, treated with surgery, radiation, chemotherapy, and antibody-mediated receptor targeted therapy, etc., patients still suffer from unfavorable prognosis.

Epidermal growth factor receptor (EGFR, ErbB-1 or HER1) over -expression can be detected on numerous epithelium-originated tumor cells, especially those generated from respiratory and digestive systems [3]. It is clear that more than two third of breast cancers express
EGFR abnormally [4], and $90 \%$ of pancreatic cancer patients, of which the 5-year survival rate is less than $5 \%$, overly express EGFR or it's ligands, such as TGF $\alpha$ and EGF [5-6]. Non-small cell lung cancers (NSCLC) and head-and-neck cancers (HNC) also showed EGFR overexpression [7-8]. Glioblastomas exhibit EGFR overexpression in more than $4 / 5$ of cases and more than half of those were tested with an additional expression of the EGFR deletion variant EGFRvIII [9-10]. Furthermore, as EGFR has been known to be pivotal for proliferation, cell survival, and vascularization, implicating that it is overexpression is a crucial factor for tumor initiation, progression and neovascularization [11], which means that the treatments aiming to blocking EGFR can be an effective way for curing cancer.

In the early $90 \mathrm{~s}$, the heavy-chain antibodies (HCAbs, $-95 \mathrm{kDa}$ ) were constructed by Hamers-Casterman, etc 
[12]. These synthetic antibodies consist of two identical heavy chains but without light chain. Unlike singlechain $\mathrm{Fv}(\mathrm{scFv})$, HCAbs, which retain high antigenbinding capacities, do not stick to each other or gather into pieces. The variable domain of the heavy chain from HcAbs (i.e.VHH), known as nanobodies or single domain antibodies, are well-functioned and they are considered to be the smallest nature-derived fragments able to combine the target protein to date [39]. Compared with conventional antibodies, the obvious advantages of nanobodies including low molecular weights, out-standing structural stability [13], and high solubility [14]. Moreover, it is easily available through phage display technology [15], and engineered into multivalent and multi-specific formats ,and then can be fused with other proteins by recloning [16]. Based on the data collected by Ablynx NV (Belgium) in a Phase I trial, nanobodies have lower level of immunogenic potential for the reason that the amino acid sequence and the conformation of $\mathrm{VHH}$ and that of human $\mathrm{VH}$ of family III are extremely alike [17-18]. However small it is, nanobodies cannot penetrate cytomembranes freely. It is highly possible that the nanobodies target cancer cells through extracellular ligands or transmembrane proteins which were expressed abnormally compared with normal cells [39]. Nanobodies, such as those against EGFR [12], Her2 [19], VEGFR2 [20], c-Met [21], CXCR7 and MUC1 [22], targeting transmembrane proteins and extracellular tumor-specific glycoproteins for cancer therapy, can be coupled with effector domain like toxins. In other words, it can be used as deliverys of conjugates for treating cancer or other diseases [23-26]. Therefore, nanobodies is in fact a targeting moiety of the whole parts of immunotoxins for cancer therapy.

Antibody-cytotoxic fusions or immunotoxins have been widely used in anti-tumor therapy nowadays [27], which mainly contains two compartments. One is the cytotoxin part which typically was plant-derived ribosomal inactivating protein (RIP) toxins (e.g. ricin, gelonin, and saporin), or bacterial toxins (e.g. diphtheria toxin, and Pseudomonas exotoxin A). The other part is usually consist of antibodies that against particular ligands [28]. This modified antibodies can function as receptors which have the ability to combine with it's ligands on the membrane surface, assisting toxin parts get into tumor cytoplasm. After that, toxin regions acquire their enzyme activities of protein synthesis inhibition, leading to tumor cell death [29-30]

Cucurmosin (CUS) extracted from pumpkin pulp is a basic alkaline glycoprotein with single polypeptide chain. After it's DNA sequences, amino acid, and the protein secondary and tertiary structures were analyzed [31-35], CUS was proved to be one of the type 1 ribosome inactivating proteins (RIPs) [36], lacking a galactosebinding lectin $\mathrm{B}$ subunit.

In this study, rE/CUS an immunotoxin, was generated by recombining the nanobody 7D12 and
CUS. As a ligand competitive inhibitor, 7D12 epitope has the capability to take up the ligand-binding site on domain III of EGFR [37], blocking the combination of EGF to the EGFR and competing for the binding site of cetuximab [38]. In order to discuss the efficacy, rE/CUS was constructed and characterized to evaluate its potential antitumor activity.

\section{RESULTS}

\section{Construction, expression, purification and identification of $\mathrm{rE} / \mathrm{CUS}$}

$\mathrm{rE} / \mathrm{CUS}$ is a chimeric protein composed of 7D12 fusing with a new type I RIP CUS, The - $\mathrm{COOH}$ terminal of 7D12 tethering the -NH2 terminal of CUS through a flexible linker $\left(\mathrm{G}_{4} \mathrm{~S}\right)_{3}$ using overlapping PCR (Figure 1). The fusion protein was sequenced and verified by Vector NTI sequence alignment analysis. All the amplified products were transferred into agarose gel for electrophoresis (Figure 2A), then the fusion gene rE/CUS was cloned into pET-32a $(+)$ and transfected into BL21 (DE3) E.coli cells and seduced by Isopropyl $\beta$-D-1-thiogalactopyranoside (IPTG). After the E.coli culture solution was collected, washed and eluted, the $\mathrm{rE} / \mathrm{CUS}$ protein was then examined through sodium dodecyl sulfate polyacrylamide gel electrophoresis (SDSPAGE). The expected molecular mass of 7D12, CUS and $\mathrm{rE} / \mathrm{CUS}$ was about $15 \mathrm{KDa}, 25 \mathrm{KDa}$ and $42 \mathrm{KDa}$ respectively (Figure 2B). As shown in Figure 2, we successfully constructed a new recombinant immunotoxin $\mathrm{rE} / \mathrm{CUS}$, and yielded $5 \mathrm{mg}$ protein from $1 \mathrm{~L}$ of bacterial culture, $\mathrm{Ni}+$ affinity chromatography column was used for enriching target protein by trapping the $6 \times$ His tag on the terminal side of amino acids. CUS and $\mathrm{rE} / \mathrm{CUS}$ was then migrated on $12 \%$ SDS-PAGE and identified through Western blot analysis (Figure 2C and 2D). The mouse anti-CUS and the mouse anti-HIS specific band appeared. This finding indicated the expressed protein was the expected immunotoxin.

\section{EGFR expression on cell lines}

EGFR expression on cell lines (HepG2, A549, SW116 and SW620) was detected by Flow cytometry. The cetuximab was used as the primary antibody and the anti-human-FITC was used as the second antibody. The percentage of EGFR expression on tumor cell lines A549, HepG2, SW116 calculated from the corresponding dot plot was $55.6 \%, 79.6 \%$ and $97.1 \%$, respectively, but SW620 was only $4.45 \%$ (Figure 3). As these data is shown, the positive cell lines A549, HepG2, SW116 was highly expression EGFR compared with negative cell line SW620.

\section{rE/CUS binding ability}

In order to prove that the reconstructed antiEGFR antibody retained binding ability to EGFR after 


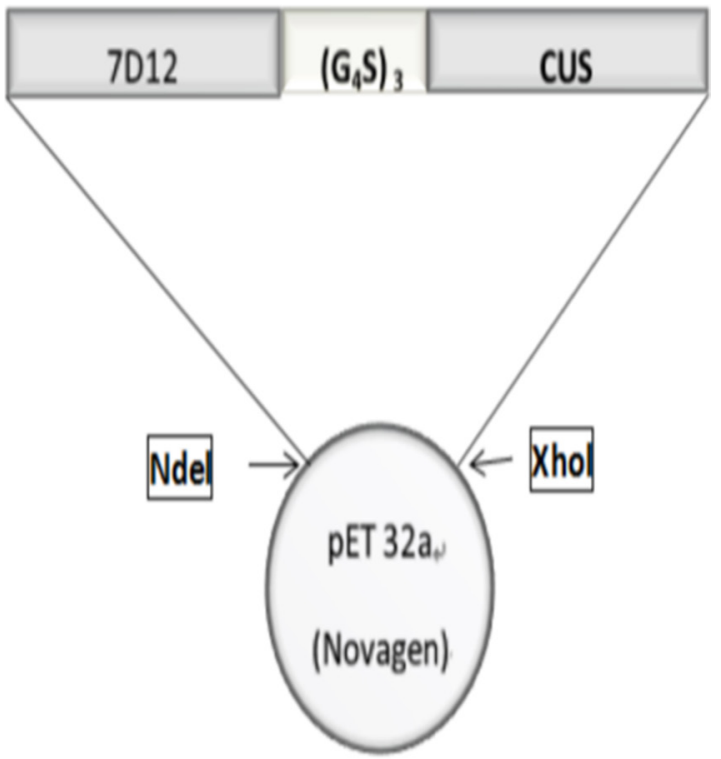

\section{Bacterial expression vector pET-32a (+)-rE/CUS}

Figure 1: The schematic diagram of recombinant immunotoxin rE/CUS. 7D12, EGFR specific nanobody. $\left(\mathrm{G}_{4} \mathrm{~S}\right)_{3}$, flexible linkers consisting of glycine and serine residues; CUS, cucurmosin.

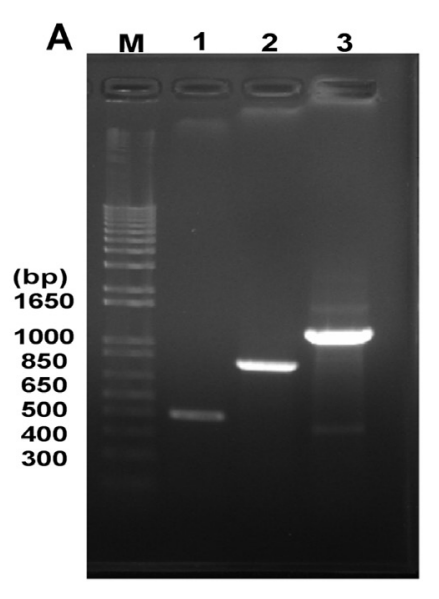

C

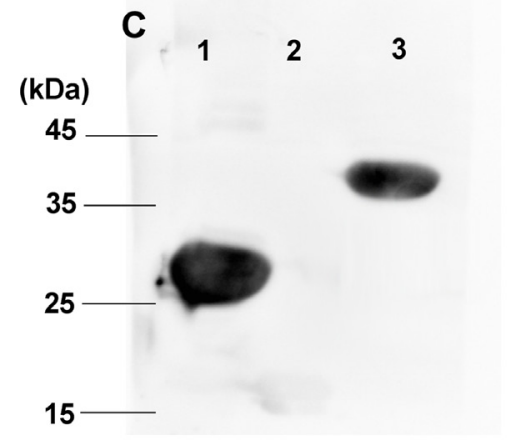

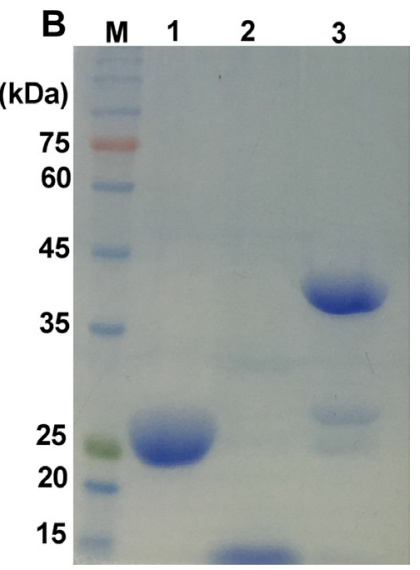

D
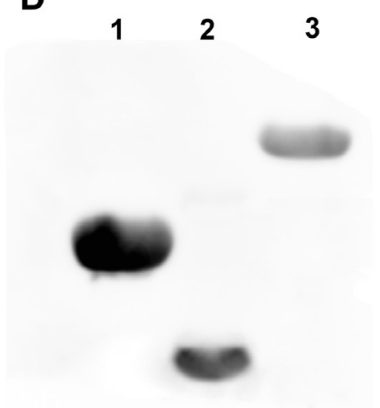

Figure 2: Construction, expression and purification of rE/CUS. (A) Agarose gel for electrophoresis of all the amplified products, M: DNA maker, Lane 1: 7D12 PCR amplification products, lane 2: CUS PCR amplification products, lane 3: rE/CUS PCR amplification products. (B) SDS-PAGE analysis of the purification immunotoxin rE/CUS, M: protein maker, lane1: purification of CUS protein, lane 2: purification of 7D12 antibody, lane 3: purification of rE/CUS protein. (C) and (D) Western blot analysis identified the immunotoxin of rE/ CUS, (C) lane 1: protein CUS, lane 2: protein 7D12, lane 3: protein rE/CUS, with mouse anti-CUS as the primary antibody, and goat antimouse HRP as the secondary antibody. (D) lane 1: protein CUS, lane 2: protein 7D12, lane 3: protein rE/CUS, with mouse anti-HIS as the primary antibody, and goat anti-mouse HRP as the secondary antibody. 
fusion, EGFR-positive cells lines HepG2, A549, SW116 and EGFR-negative cell line SW620 were treated with $30 \mu \mathrm{mol} / \mathrm{L}$ of $7 \mathrm{D} 12$ and $\mathrm{rE} / \mathrm{CUS}$, then mouse anti-HIS antibody and the goat anti-mouse-APC were added for reconstructed immunotoxin binding analyzing using Flow cytometry. Data displayed that 7D12 and rE/CUS were able to combine with EGFR positive cells HepG2, A549, SW116 but cannot conglutinate to negative cell line SW620 (Figure 4).

\section{In vitro cytotoxicity of $\mathrm{rE} / \mathrm{CUS}$}

Data shows that the immunotoxin $\mathrm{rE} / \mathrm{CUS}$ remains antigen binding capability. We then evaluated the cytotoxicity of rE/CUS through SRB assay. The protein CUS, 7D12 and rE/CUS were tested by co-culturing with a number of tumor cell lines for $72 \mathrm{~h}$ (Figure 5). The results illustrates that CUS and $\mathrm{rE} / \mathrm{CUS}$ can significantly inhibited the cells viability through a dose-dependent manner, but there is barely cytotoxin effects of 7D12 on the same cell lines. The IC50 of rE/CUS was significantly lower than CUS whose IC50 value act on HepG2, A549,

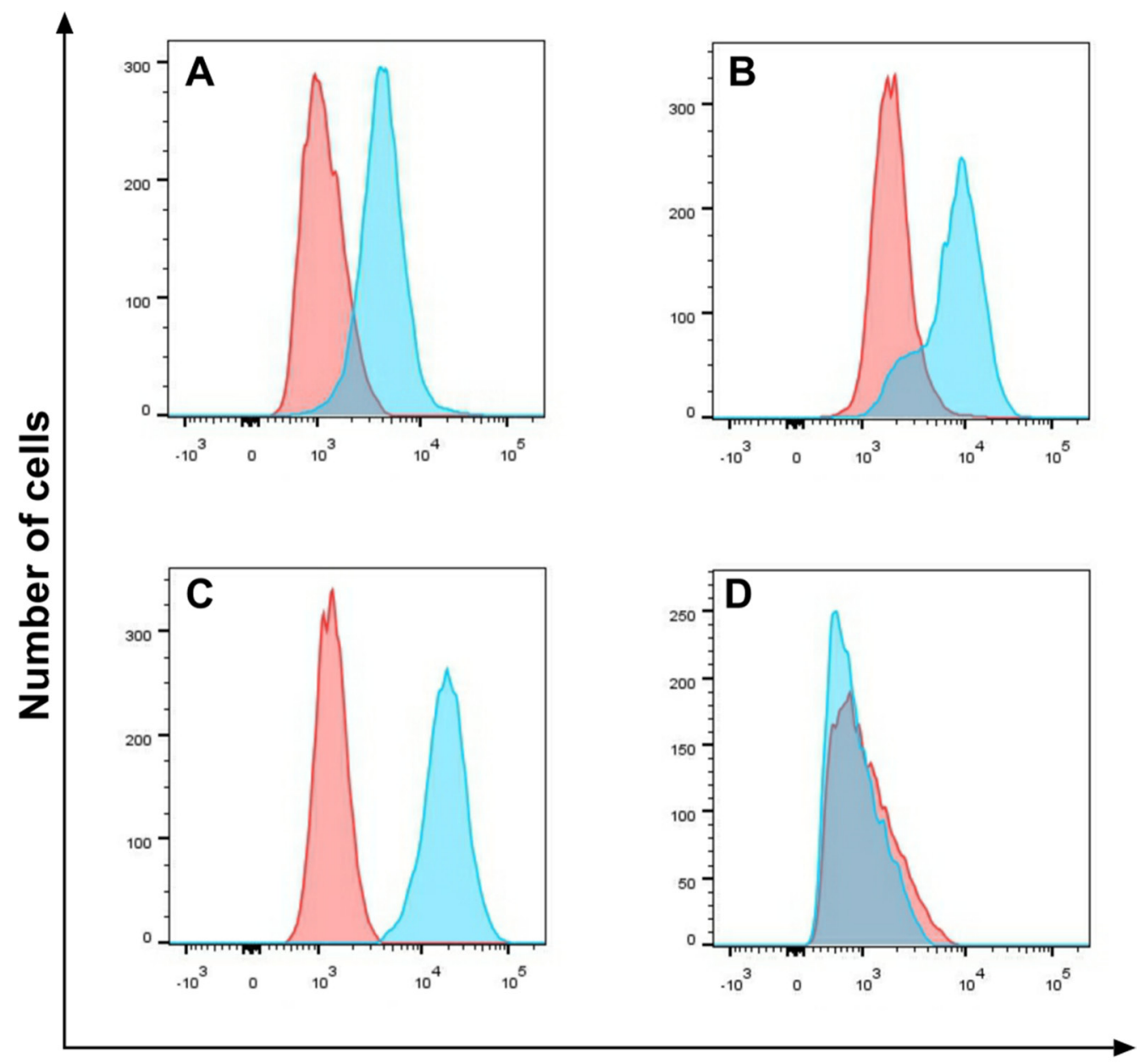

\section{Alexa Fluor 488}

Figure 3: EGFR expression on cell lines. EGFR expression on A549 (A), HepG2 (B), SW116 (C) and SW620 (D) was detected by flow cytometry, the red part was untreated group, and the blue part was treat group.

SW116 was 217, 39, 89-fold higher than that of rE/CUS. The negative cell SW620 showed little cytotoxicity of rE/ CUS compared with CUS itself (Table 1).

The IC50 of rE/CUS, which reflects the it's cytotoxicity effects is not only dose dependent but time dependent (Figure 6), and were different with that of CUS in 2-5 days. Although both $\mathrm{rE} / \mathrm{CUS}$ and CUS significantly reduced cell viability, $\mathrm{rE} / \mathrm{CUS}$ elicited a greater effect on cell viability than CUS did.

\section{Cells inhibition of cell proliferation induced by rE/CUS via apoptosis}

The proliferation of EGFR highly expression cells was evidently inhibited by $\mathrm{rE} / \mathrm{CUS}$. We then investigated whether the cellular growth inhibitor was induced via apoptosis. We examined HepG2 and A549 cells by using Annexin V-FITC/PI. After the cells were treated with gradient concentrations of $\mathrm{rE} / \mathrm{CUS}$ for $72 \mathrm{~h}$, the significant apoptosis of it induced by $\mathrm{rE} / \mathrm{CUS}$ can be observed (Figure 7). The lower right quadrant indicates 
Table 1: SRB assay results of various tumor cell lines treated with gradient concentrations of CUS and $\mathrm{rE} / \mathrm{CUS}$ for $72 \mathrm{~h}$

\begin{tabular}{cccc}
\hline \multirow{2}{*}{ cell line } & \multicolumn{2}{c}{ IC50(nmol/L) } & \multirow{2}{*}{$\boldsymbol{P}$ value } \\
\cline { 2 - 3 } & rE/CUS & CUS & $0.0018^{\mathrm{a}}$ \\
HepG2 & $2.15 \pm 0.226$ & $466.3 \pm 0.483$ & $0.0006^{\mathrm{a}}$ \\
A549 & $18.33 \pm 0.018$ & $716 \pm 0.760$ & $0.003^{\mathrm{a}}$ \\
SW116 & $2.33 \pm 0.032$ & $208.33 \pm 0.056$ & 0.0265 \\
\hline
\end{tabular}

Data shown are IC50 (mean $\pm \mathrm{SD}$ ). ${ }^{\mathrm{a}}$ Compared with CUS, $p<0.05$; SRB, sulforhodamine B.

the proportion of cells in early apoptosis, the upper right quadrant shows the population of the late apoptotic or necrotic cells, and the upper left quadrant shows the necrotic cells. The total percentage of apoptosis includes early and late stages of apoptotic cells. Cell apoptosis were significantly induced by different concentrations of rE/CUS. For HepG 2 cell line, approximately $40 \%$ of the cells were killed in corresponding concentration, and the apoptosis of A549 was around 70\%. The untreated group showed a weak or even no apoptotic effect.

\section{DISCUSSION}

EGFR overexpression is correlated with the increased aggressiveness, metastases, and poor prognosis in various cancers [39], including head and neck cancer, colorectal cancer, pancreatic, lung cancer, renal cell, prostate carcinoma and malignant glioma [40-41].
Therefore, it is necessary for anti-EGFR therapeutic strategies to be improved.

Monoclonal antibodies (mAbs) is a crucial part of the development of cancer therapy [42-43]. One of it's anti-tumor mechanisms is through binding the receptors that are expressed on the cellular surface or secreted in body fluids, after that the signal transduction pathways of cancer cells would be influenced, resulting the inhibition of tumor's proliferation and angiogenesis. Also, because of the presence of the intact Fc domain, the mAbs have the potential to induce antibody-dependent cell-mediated cytotoxicity (ADCC) by recruiting effector immunocytes and cytokines of immune system into the tumor microenvironment, which tend to further enhance the antitumor efficacy. Further more, as monoclonal antibodies can be used as a payload of non-specific cytotoxin, forming into nanomedicines (e.g. auristatin, maytansine, or doxorubicin) [39], it is capable of causing tumor specific

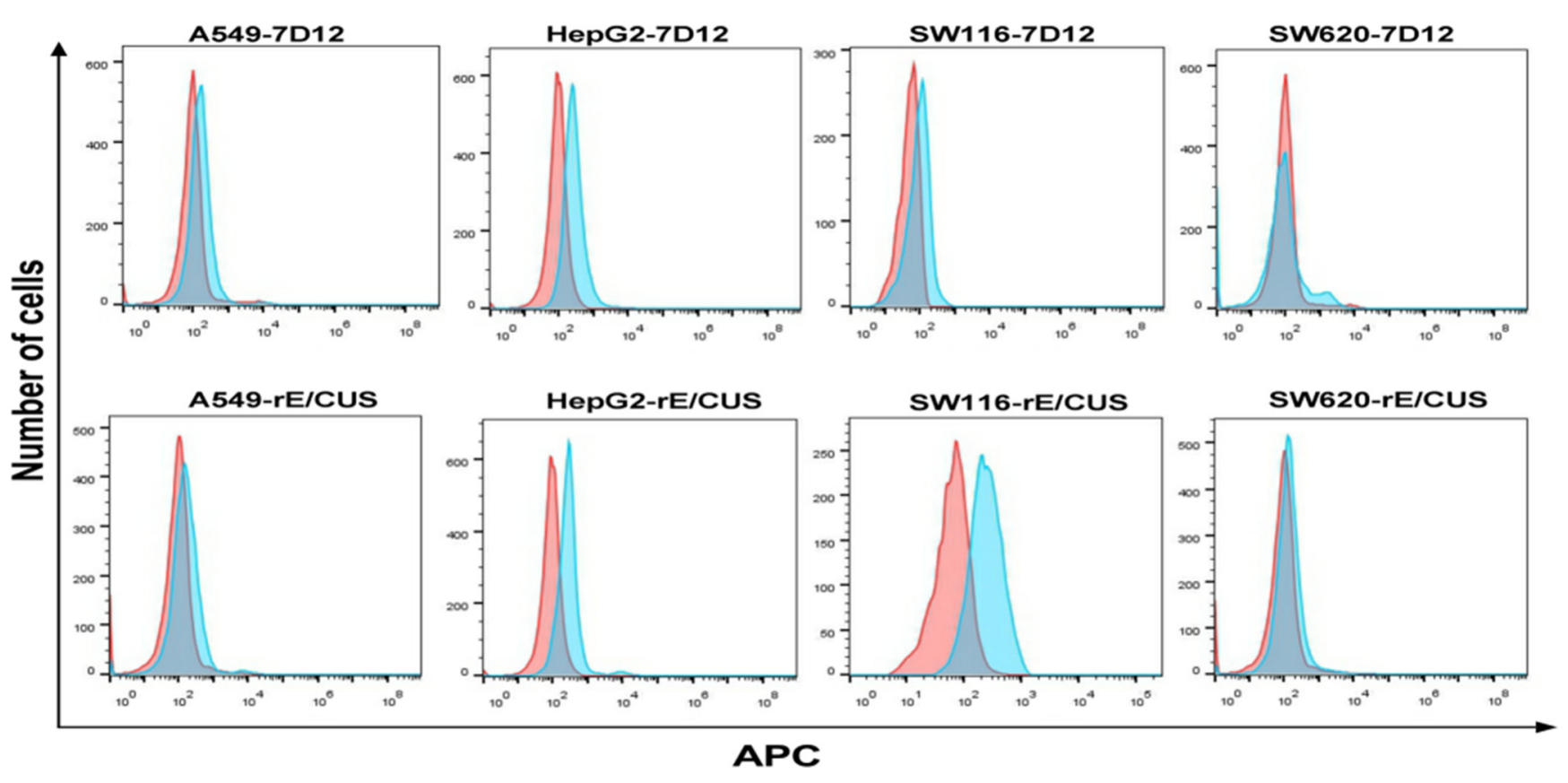

Figure 4: Analysis of binding ability of rE/CUS to tumor cell lines by Flow cytometry. EGFR-positive cell lines HepG2, A549, SW116 and EGFR negative cell line SW620 were treated with 7D12 and rE/CUS. Cells were incubated with mouse anti-HIS antibody and the mouse anti-HIS-APC, then analyzed by Flow cytometry. 
cytotoxic effects [44]. Recently, the first antibody-drug conjugates(ADCs), Trastuzumab emtansine, was approved in treating patients with HER2-positive locally advanced breast cancer which is unresectable [45-46], indicating a bright future of the utilization of ADCs in clinic .

Target EGFR therapeutic monoclonal antibodies, namely cetuximab, panitumumab and some small tyrosine kinase inhibitors (TKIs), have gotten approval in treating colorectal cancer [47]. Other therapeutic monoclonal antibodies including gefitinib, lapatinib and erlotinib have been approved to be clinically effective in cancer treatment [48-51]. Nevertheless, the primary or acquired resistance of TKIs limits the application of these drugs, which are likely to be related with the constitutive stimulation of downstream molecules or over-expression of other tyrosine-kinase receptors [52]. For example, the sustaining activation of the downstream signaling paths MAPK and PI3K/Akt tend to promote cell proliferation, survival, differentiation and motility [53]. And angiogenesis causing up-regulated expression of the vascular endothelial growth factor (VEGF) on human cancer cells by it's ligands such as EGF and TGF- $\alpha$ can also be a factor to induce resistance to EGFR blocking agents [54]. Unlike TKIs, the immunotoxins $\mathrm{rE} / \mathrm{CUS}$, like D2C7-(scdsFv)-PE38KDEL which can be activated in glioblastoma patients expressing wild-type EGFR only or co-expressing wild-type EGFR and EGFRvIII [55], is solely depends on the expression of EGFR rather than tyrosine kinase signaling cascade triggered by EGFR. The target moiety of rE/CUS specifically binds to EGFR overexpression tumor cells and internalized the new type I RIP mediated by receptor, then the adenosine from the $28 \mathrm{~S}$ ribosomal RNA were removed from RIPs, as a result,the RNA translation was interfered, leading to the protein biosynthesis inhibition [56-57].

Nanobody 7D12, with $15 \mathrm{KDa}$ molecular mass sterically blocks it's ligand by binding to EGFR in a cetuximab-like manner [40]. Compared with traditional antibody, 7D12 alleviates immunogenicity result from particle size, and may shorten circulating time in the blood [58]. Previous research has shown that CUS is capable of inhibiting the proliferation of various tumor cells significantly, with a lethal activity four to seven times stronger than that of other type I RIPs, namely trichosanth, luffaculin, and amaranth protein [59].

To some extent, the advantages of recombinant immunotoxins outweigh chemically-linked conjugates. As integrate molecules, recombinant immunotoxins can be easily produced and purified [60-61]. Their cytotoxic potency, stability and affinity can be modified through
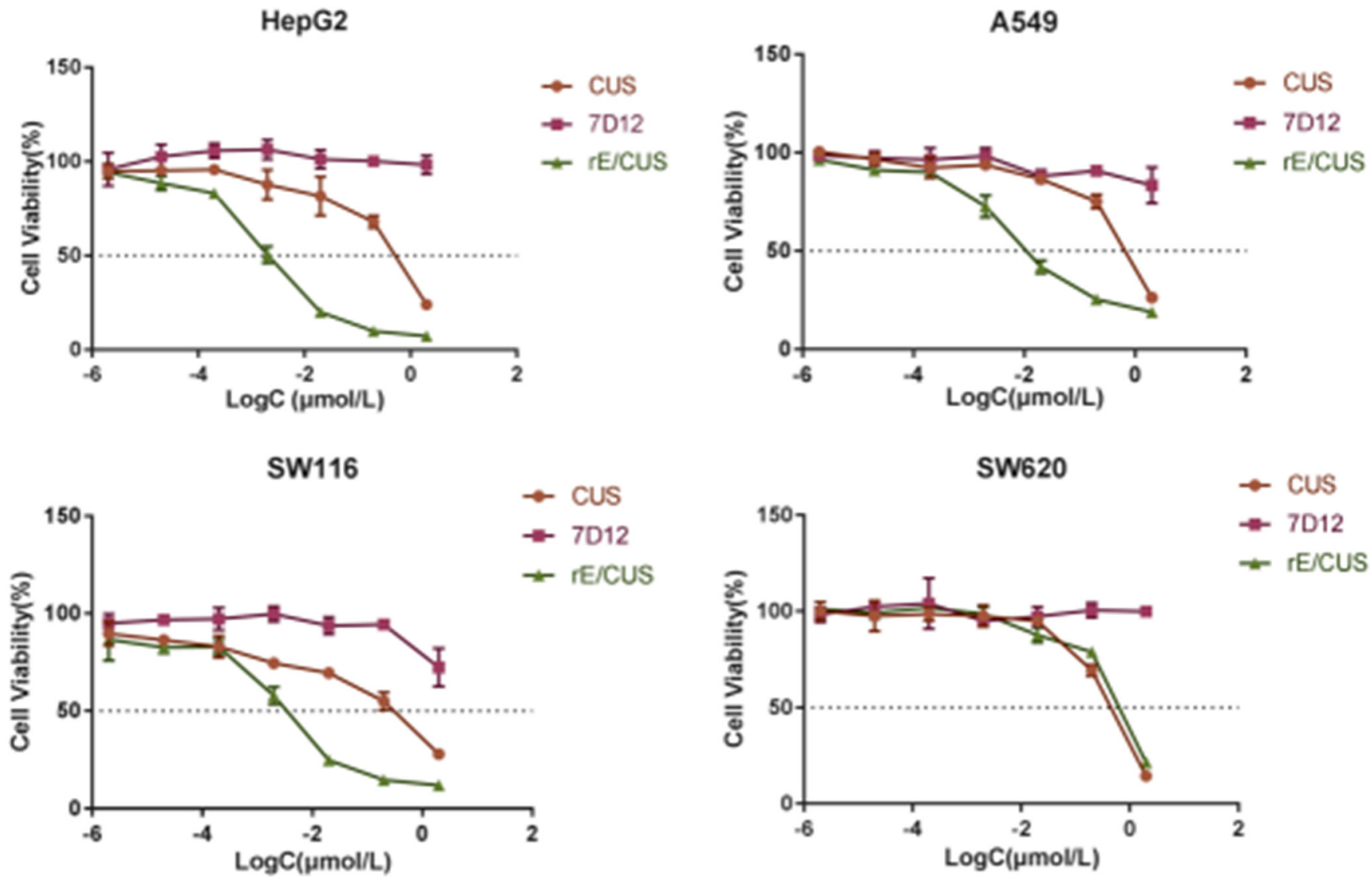

Figure 5: Cytotoxicity of rE/CUS in HepG2, A549, SW116 and SW620 cells through SRB assay. log-normal distribution model is applied.The viability of cells is the percentage of cells alive after treating with rE/CUS, CUS and 7D12. Points represent the mean of 3 independent experiments; bars represent the SD. 
genetic engineering technology [62-63]. In the mean time, the heterogeneity of conjugation products and doselimiting side effects such as vascular leak syndrome can be mitigated by humanization or reconstruction [64].

This study aimed to construct a new EGFR-specific recombinant immunotoxin $\mathrm{rE} / \mathrm{CUS}$, and evaluate it's antitumor activity in vitro. The recombinant immunotoxin $\mathrm{rE} / \mathrm{CUS}$ was constructed by connecting the 7D12 gene to the CUS with a flexible linker $\left(\mathrm{G}_{4} \mathrm{~S}\right)_{3}$, The expression vector pET23 (a) containing desired gene was then transferred into prokaryotic expression system, and the $\mathrm{Ni}^{+}$ affinity chromatography column were used in the process of $\mathrm{rE} / \mathrm{CUS}$ purification. Western blot analysis exhibiting the mouse anti-CUS and mouse anti-HIS specific band, proving that the protein is a soluble. The mass of protein $\mathrm{rE} / \mathrm{CUS}$ is approximately $42 \mathrm{KDa}$ by theoretical calculation, and the SDS-PAGE analysis of the purified protein showed that the bands were what we expected. These results demonstrate that we constructed a new recombinant immunotoxin.

The cytotoxic activity of $\mathrm{rE} / \mathrm{CUS}$ was assessed for it's anticancer capability. Compared with 7D12 alone, the recombinant immunotoxins $\mathrm{rE} / \mathrm{CUS}$ could effectively stick to EGFR highly expressing cells, which means that the antigen binding capability of $\mathrm{rE} / \mathrm{CUS}$ was not affected by the extra-components of CUS and the delivery of CUS producing an impressive cytotoxic effects on tumor cell lines. $\mathrm{rE} / \mathrm{CUS}$ significantly inhibited the cell viability against various EGFR highly expression tumor cell lines in a dose-and time-dependent manner. The cytotoxic activity of rE/CUS against cell lines HepG2, A549 and SW116 which the EGFR expression were upregulated were highly sensitive to the rE/CUS. Whereas those whose EGFR expression were lower (SW620) showed no cell-lethal effects. The IC50 values of $\mathrm{rE} /$ CUS in different cell lines were much lower than those of CUS, and the IC50 values of 7D12 alone showed no difference with control group. The same dose of rE/CUS has different effects in different times tend to result from the internalization of the toxin [65]. Moreover, rE/CUS also significantly reduced the proliferation of HepG2 and A549 by inducing $>70 \%$ and $>40 \%$ apoptosis at a series of concentration. The specific toxicity of $\mathrm{rE} / \mathrm{CUS}$ on HepG2 and SW116 were much stronger than other cell lines, with the IC50 value at $2.15 \mathrm{nmol} / \mathrm{L}$ and $2.33 \mathrm{nmol} / \mathrm{L}$.

The binding ability of $\mathrm{rE} / \mathrm{CUS}$ was lower than cetuximab and trastuzumab in the same concentration (data not shown). Chemically-linked conjugates Cetuximab-Cucurmosin and Trastuzumab- Cucurmosin were also constructed by our group [66-67]. CetuximabCucurmosin were added in cultural medium of human colorectal cancer cell lines HCT116, SW480 for 5 day, and normal liver cells Lovo was used as negtive control cells. The IC50 of it was $(0.075 \pm 0.02) \mathrm{pmol} / \mathrm{L},(0.058 \pm 0.012)$ $\mathrm{pmol} / \mathrm{L},(0.511 \pm 0.063) \mathrm{pmol} / \mathrm{L}$ which showed a significant time and dose-dependent proliferation inhibition, and the tumor inhibition rate of Cetuximab-Cucurmosin $(20 \mu \mathrm{g})$ were $48.625 \%$. The IC50 of Trastuzumab-Cucurmosin on human breast cancer cell lines BT474 and human ovary cancer cell lines SK-OV-3 for 5 day were $(0.0227$ $\pm 0.007) \mathrm{nmol} / \mathrm{L},(0.00252 \pm 0.0054) \mathrm{nmol} / \mathrm{L}$. The IC50 of Trastuzumab-Cucurmosin on BT474 is lowerer than Chemically-linked conjugates trastuzumab-DM1 (TDM1) and Trastuzumab-deBouganin conjugates(T-
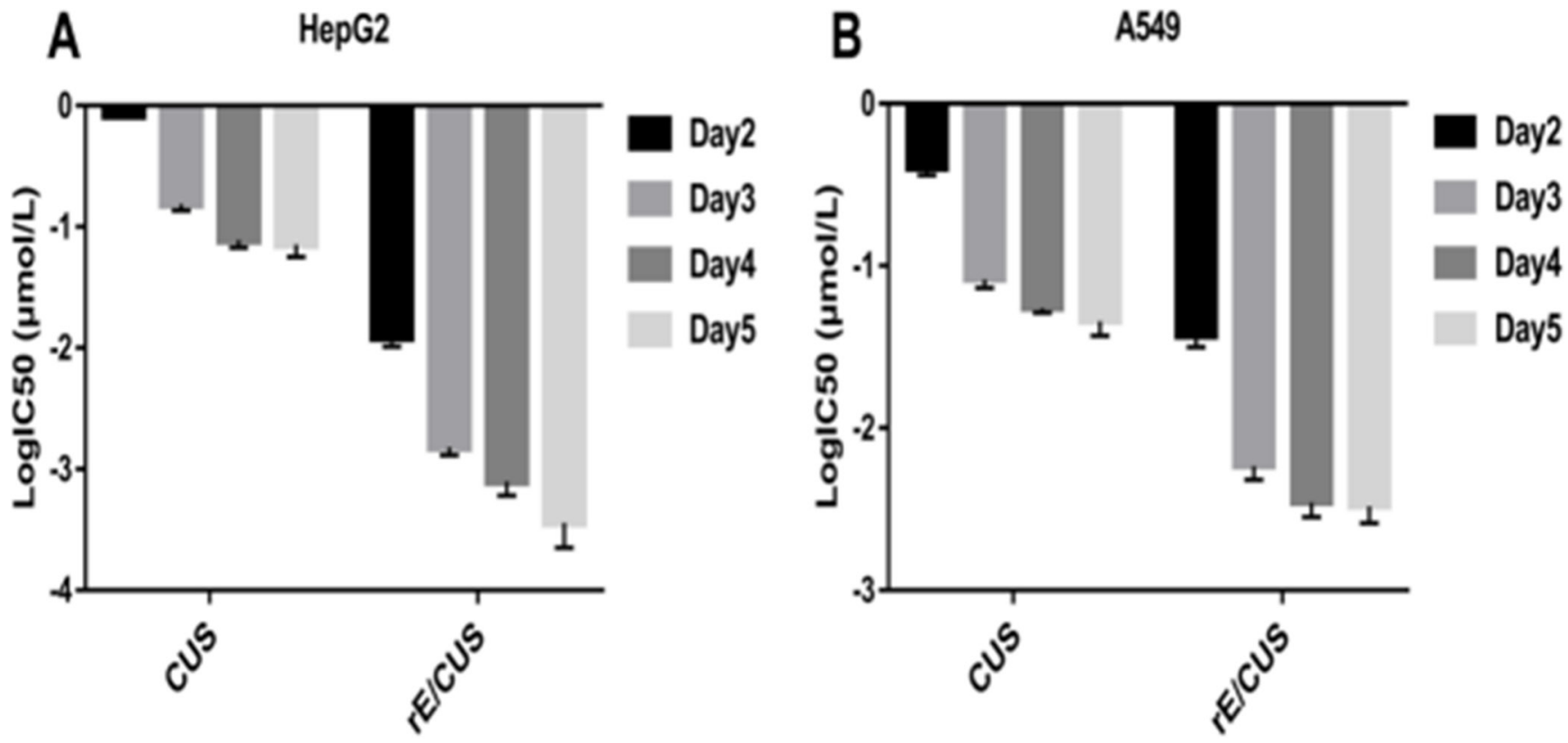

Figure 6: Dose-and time-dependent of the inhibitory effect of $\mathrm{rE} / \mathrm{CUS}$ on the proliferation of HepG2 and A549. (A and B) IC50 values of CUS and rE/CUS in HepG2 and A549 for day 2-5 days. 
deB) [68]. It is believed that the CUS is a promising toxin molecule for cancer therapy. In order to improve the binding ability of rE/CUS, we further designed and constructed an immunotoxin based CUS using a bivalent or biparatopic nanobodies as the target moiety. rGel-based immunotoxins used in cancer therapy showed that there is a strong correlation between the internalization percentage via receptor-mediated endocytosis [69]. Bivalent or
A
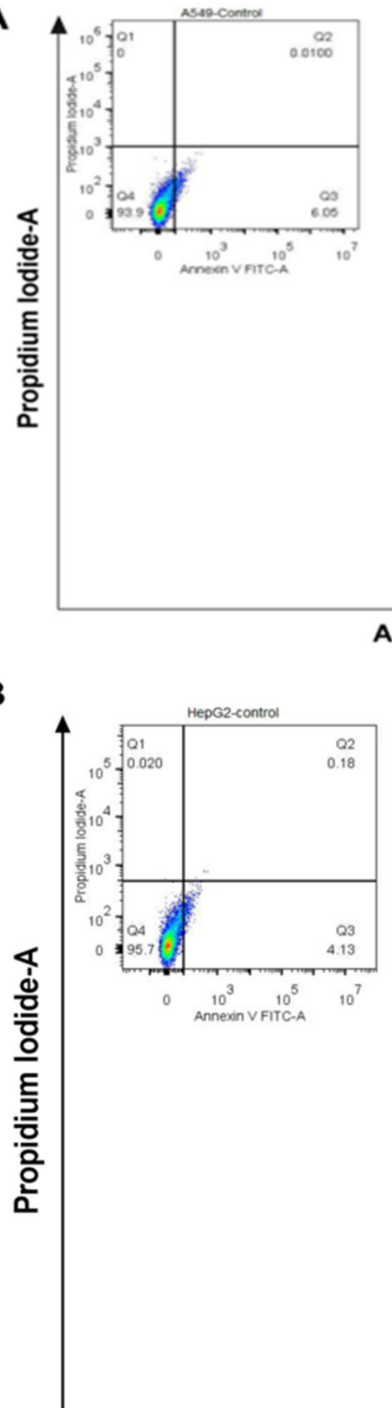

B
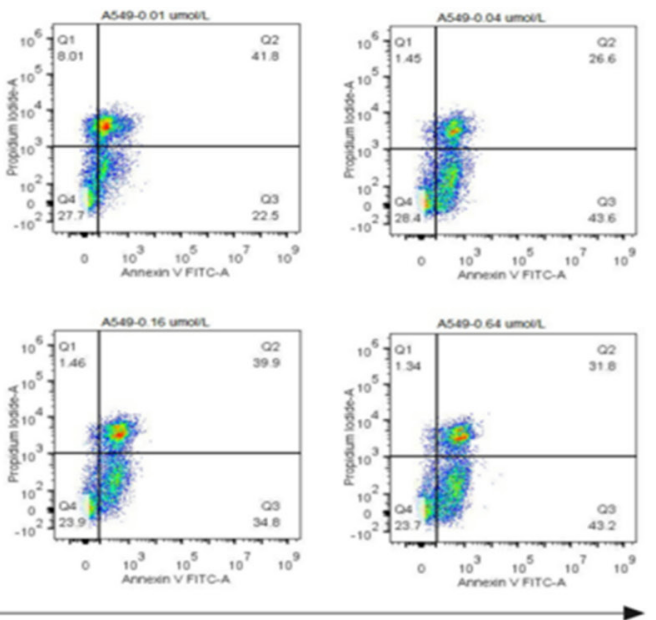

Annexin V FITC-A
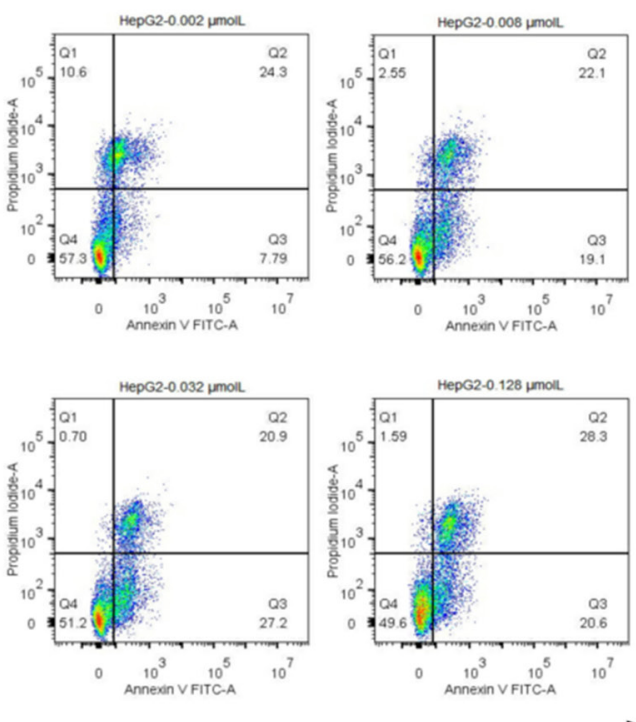

Annexin V FITC-A
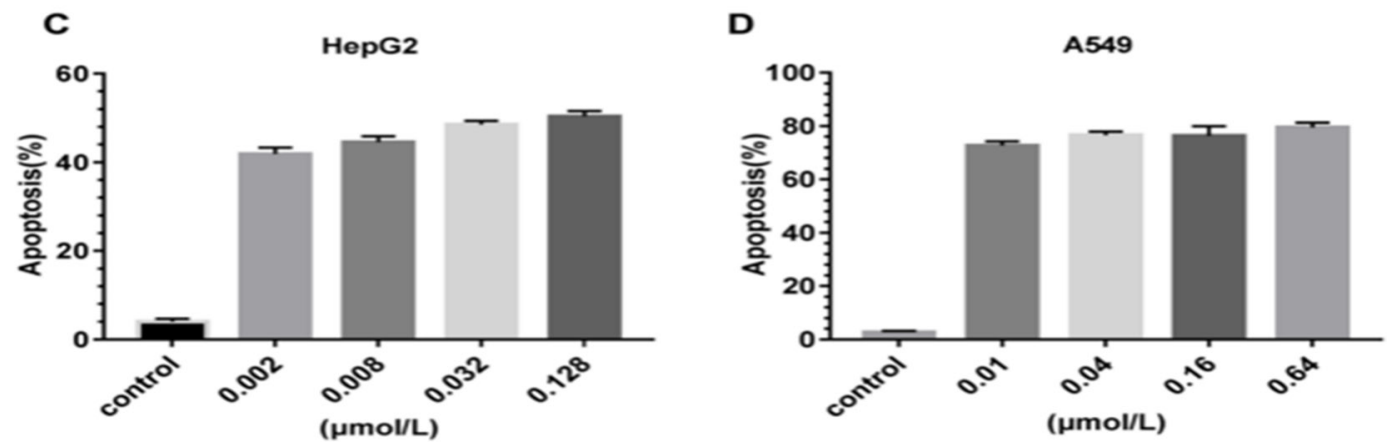

Figure 7: Apoptosis analysis of the immunotoxins rE/CUS. (A) on A549, which incubated with 0.01, 0.04, 0.16 and 0.64 $\mu$ mol/L of rE/CUS for $72 \mathrm{~h}$, dot blots and the percentage of the four quadrants. (B) on HepG2, which was incubated with $0.002,0.008,0.032$, and $0.128 \mu \mathrm{mol} / \mathrm{L}$ of $\mathrm{rE} / \mathrm{CUS}$ for $72 \mathrm{~h}$, dot blots and the percentage of the four quadrants. (C and D) Early and late apoptosis or necrosis was combined in a column diagram foreach cell line for A549 and HepG2. 
biparatopic nanobodies have more intensive ability to block EGFR activation than monovalent nanobodies do. Previous studies have also demonstrated that bispecifc single-chain immunotoxins, such as CONAN-1 which elicits a potent inhibitory effect on tumour growth [39], were more effective than monospecifc or bivalent immunotoxins in vitro and in vivo [70-71]. Meanwhile, as nanobodies can be easily formatted that it can be constructed into bispecifc immunotoxins, like bivalent immunotoxin PG002, which engage two different epitopes or antigens on cancer cells [72].

In conclusion, a new recombinant immunotoxin linking 7D12 with CUS was designed, constructed, and expressed. It is specifically lethal to EGFR highly expression tumor cell lines in vitro. Our results exhibited that $\mathrm{rE} / \mathrm{CUS}$ could be a potential therapeutic strategy in treating EGFR-positive solid tumors.

\section{MATERIALS AND METHODS}

\section{Materials}

pET-32a vector $(+)$ and E.coli BL21 (DE3), histagged fusion protein kit and western blot antibodies were obtained from Sangon Biotch in Shanghai. The Plasmid Midi Kits were purchased from Gene Mark, and mRNA isolation kits were from CWBIO.

Human hepatoma cell HepG2, human NSCLC A549, human colorectal cancer cell SW116 and human colon cancer cell SW620 cell lines were acquired from cell bank / stem cell bank of the Chinese Academy of Sciences. RPMI-1640 supplemented with $0.292 \mathrm{~g} / \mathrm{L}$ L-glutamine, $2 \mathrm{~g} / \mathrm{L}$ sodium hydrogen carbonate, and $800 \mathrm{U} / \mathrm{L}$ gentamicin were used for cells culture. Humidified incubator with temperature of $37^{\circ} \mathrm{C}, \mathrm{CO}_{2}$ concentration of $5 \%$, were used for cells maintaining.

\section{Methods}

\section{Construction of aprokaryotic-expressing plasmid}

Competitive inhibitor 7D12 was generated with Ablynx NV as described previously [12]. The geneencoding CUS was obtained from our laboratory patent(CN 101215327A) whichwere already constructed in plasmid. 7D12 and CUS sequence was amplified through PCR from plasmids pET-32a-7D12 and pET-32aCUS, the 7D12 gene was then connected to CUS with the linker $\left(\mathrm{G}_{4} \mathrm{~S}\right)_{3}$ by overlapping PCR. After agarose gel electrophoresis was performed, the amplified products were digested, purified, ligated into plasmid vector $\mathrm{pET}$ 32a with Ndel and Xhol restriction enzyme cutting sites linking with the target fragment and vector. The fusion gene $\mathrm{rE} / \mathrm{CUS}$ was cloned into E.coli expression vector, pET-32a (+). The expression vector pET-32a (+) -rE/CUS was identified though restriction enzyme digestion and DNA sequencing.

\section{Protein expression, isolation, and purification}

The expression vector pET-32a (+)-rE/CUS was transfected into BL21 (DE3) E.coli cells. The bacterial culture medium containing $50 \mu \mathrm{g} / \mathrm{ml}$ ampicillin were shaken at $200 \mathrm{rpm}$ at $37^{\circ} \mathrm{C}$ until the it reached the log phase where $A 600 \mathrm{~nm}$ is approximately 0.6 . Then 200 $\mu \mathrm{g} / \mathrm{ml}$ Isopropyl $\beta$-D-1-thiogalactopyranoside (IPTG) were added for protein expression induction. Before the bacterial cultures were harvested through centrifugation ( $8000 \mathrm{rpm}, 20 \mathrm{~min}, 4^{\circ} \mathrm{C}$ ), the bacterial culture medium were shaken at $200 \mathrm{rpm}$ at $25^{\circ} \mathrm{C}$ for $16 \mathrm{~h}$. Then the pellets were resuspended in $0.015 \mathrm{~mol}$ PBS after $8000 \mathrm{rpm}$ washing for $10 \mathrm{~min}$ at $4^{\circ} \mathrm{C}$. As a total volume of $3 \mathrm{~L}$ bacterial culture centrifuged into pellet then resuspended in $30 \mathrm{ml}$ Tris- $\mathrm{NaCl}$ and $30 \mathrm{mg}$ lysozyme, and pulsesonicated for $90 \mathrm{~min}$ on ice, the supernatant of solution was seperated at $8000 \mathrm{rpm}$ for $10 \mathrm{~min} 4^{\circ} \mathrm{C}$. In purification process, the specimen was washed with $50 \mathrm{mmol}$ Tris, $300 \mathrm{mmol} \mathrm{NaCl}, 15 \mathrm{mmol}$ imidazole, and the protein was eluted with $50 \mathrm{mmol}$ Tris, $300 \mathrm{mmol} \mathrm{NaCl}$, and $150 \mathrm{mmol}$ imidazole according to His-tagged fusion protein kit. Then it was examined through sodium dodecyl sulfate polyacrylamide gel electrophoresis (SDS-PAGE). Finally, the product expressed was dialyzed, filtersterilized, and stored at $4^{\circ} \mathrm{C}$.

\section{Western blot analysis}

Purified protein was analyzed through Western blot analysis with a mouse anti-HIS antibody and mouse anti-CUS antibody as primary antibody. The horseradish peroxidase-(HRP-) labeled goat anti-mouse IgG was selected as the secondary antibody.

\section{Flow cytometry of EGFR expression on different cell lines}

Human hepatoma cell HepG2, human nonsmall cell lung cancer A549, human colorectal cancer cell SW116 and human colon cancer cell SW620 was detected by FACS Calibur (BD Biosciences) at Alexa flour 488. Scatchard plots were generated and analyszed using FlowJo V10. The cells were harvested at 2000 rpm for $5 \mathrm{~min}$, then washed at $2000 \mathrm{rpm}$, for $5 \mathrm{~min}$ by PBS containing $1 \%$ bovine serum albumin (BSA). The cetuximab was used as the primary antibody and the antihuman-FITC was used as the second antibody at $4{ }^{\circ} \mathrm{C}$ for $30 \mathrm{~min}$. The cells were washed and analyzed by flow cytometry. Each experiment was repeated thrice.

\section{Flow cytometric detection of $\mathrm{rE} / \mathrm{CUS}$ binding capability}

rE/CUS binding capability was detected by FACS Calibur (BD Biosciences). HepG2, A549, SW116 and SW620 cells were harvested, $2000 \mathrm{rpm}, 5 \mathrm{~min}$, then washed with PBS containing 1\% BSA, $2000 \mathrm{rpm}$, and $5 \mathrm{~min}$. then cells were incubated with the $30 \mu \mathrm{M} \mathrm{rE} / \mathrm{CUS}$ for $30 \mathrm{~min}$ at $4^{\circ} \mathrm{C}$. The cells were incubated with mouse anti-HIS antibody for $30 \mathrm{~min}$ at $4^{\circ} \mathrm{C}$, and then incubated 
with mouse anti-HIS-APC for $30 \mathrm{~min}$ at $4^{\circ} \mathrm{C}$. The cells were washed and analyzed using flow cytometry. Each results was testified thrice.

\section{In vitro cytotoxicity assays}

\section{Detecting of Inhibition of rE/CUS Proliferation for $72 \mathrm{~h}$}

Positive cells (HepG2, A549 and SW116) overly express EGFR, and negative cells (SW620 cell) were seeded in 96-well plates with $4 \times 10^{4} / \mathrm{ml}$ per well, then the cells were incubated for $24 \mathrm{~h}$ to adherence in $5 \%$ $\mathrm{CO}_{2}$ at $37^{\circ} \mathrm{C}$. When in the logarithmic phase, the cells were subsequently treated with rE/CUS, CUS and 7D12 at different concentrations and incubated for $72 \mathrm{~h}$ at $5 \%$ $\mathrm{CO}_{2}, 37^{\circ} \mathrm{C}$. Before detection, trichloroacetic acid was added, and the cells were incubated at $4^{\circ} \mathrm{C}$ overnight. And washed five times with $\mathrm{H}_{2} \mathrm{O}$. Sulforhodamine B (SRB). The cells were incubated for $30 \mathrm{~min}$ at room temperature, washed five times with $1 \%$ acetic acid, and 100nmol tris(hydroxymethyl)- amino-methane was added for absorption testing (515 nm) [73]. Each experiment was repeated thrice.

\section{Dose-and time-dependence of the inhibitory effect of $\mathrm{rE} / \mathrm{CUS}$ on the proliferation of HepG2, and $\mathrm{A549}$ cells}

HepG2 and A549cells were seeded in 96-well plates with $3 \times 10^{4} / \mathrm{ml}$ per well when cells in logarithmic phase, then the cells were incubated for $24 \mathrm{~h}$ at $5 \% \mathrm{CO}_{2}, 37^{\circ} \mathrm{C}$. Subsequently, cells were treated with rE/CUS, 7D12 and CUS at different concentrations, and incubated for 2-5 days at $5 \% \mathrm{CO}_{2}, 37^{\circ} \mathrm{C}$. Then the cell proliferation in each plate was detected at the corresponding time by SRB.Each experiment was repeated thrice.

\section{Flow cytometric analysis of cells apoptosis}

AnnexinV-FITC/propidium iodide (PI) detection kit (KeyGEN BioTech) was used to analyze cells apoptosis induced by rE/CUS. A549 and HepG2 were seeded in 6 wells plates with $4 \times 10^{4} / \mathrm{ml}$, and incubated for $24 \mathrm{~h}$ at $5 \%$ $\mathrm{CO}_{2}, 37^{\circ} \mathrm{C}$, later on $\mathrm{A} 549$ and HepG2 were treated with $\mathrm{rE} /$ CUS for $72 \mathrm{~h}$. Then the cells were harvested, washed twice with PBS containing 2\% BSA, and resuspended in binding buffer at $1 \times 10^{5}$ cells $/ \mathrm{ml}$. $5 \mu \mathrm{L}$ AnnexinV-FITC and $5 \mu \mathrm{L}$ PI were added for $15 \mathrm{~min}$ at room temperature in the dark for staining. The cells were washed and resuspended in 500 ul binding buffer, and flow cytometry were applied for analyzing. Each results was testified thrice.

\section{Statistical analysis}

SPSS 19.0 were used for analyzing the means \pm standard deviation (SD) of results, and image processing was using GraphPad Prism 7.00. Signifcant difference of 2 groups $(P<0.05)$ were compared by Student's $t$-test.

\section{ACKNOWLEDGMENTS AND FUNDING}

Thanks for the financial support of the National Science Foundation of China (no. 30772587), the Natural Science Foundation of Fujian Province (nos.C0510012, 2011J01188, and 2016J01769), and the Research Project of Fujian Medical university (2013JY018, JS14011).

\section{CONFLICTS OF INTEREST}

No potential conflicts of interest were disclosed.

\section{REFERENCES}

1. Siege R, Miller K, Jemal A. Cancer statistics. CA Cancer J Clin. 2016; 66:7-30.

2. Stewart BW, Wild CP. World Cancer Report. Lyon, France: International Agency for Research on Cancer, WHO Press. 2014.

3. Holbro T, Civenni G, Hynes NE. The ErbB receptors and their role in cancer progression. Exp Cell Res. 2003; 284:99-110.

4. Park HS, Jang MH, Kim EJ, Kim HJ, Lee HJ, Kim YJ, Kim JH, Kang E, Kim SW, Kim IA, Park SY. High EGFR gene copy number predicts poor outcome in triple-negative breast cancer. Mod Pathol. 2014; 27:1212-22.

5. Lemoine NR, Hughes CM, Barton CM, Poulsom R, Jeffery RE, Klöppel G, Hall P, Gullick WJ. The Epidermal Growth Factor Receptor in Human Pancreatic Cancer. J Pathol. 1992; 166:7-12.

6. Korc M, Chandrasekar B, Yamanaka Y, Friess H, Buchier M, Beger HG. Over expression of the epidermal growth factor receptor in human pancreatic cancer is associated with concomitant increases in the levels of epidermal growth factor and transforming growth factor alpha. J Clin Investig. 1992; 90:1352-60.

7. Rubin GJ, Melhem MF, Barnes EL, Tweardy DJ. Quantitative immunohistochemical analysis of transforming growth factor- $\alpha$ and epidermal growth factor receptor in patients with squamous cell carcinoma of the head and neck. Cancer. 1996; 78:1284-92.

8. Hirsch FR, Scagliotti GV, Langer CJ, Varella-Garcia M, Franklin WA. Epidermal growth factor family of receptors in preneoplasia and lung cancer: Perspectives for targeted therapies. Lung Cancer. 2003; 41:29-42.

9. Wikstrand CJ, Hale LP, Batra SK, Hill ML, Humphrey PA, Kurpad SN, McLendon RE, Moscatello D, Pegram CN, Reist CJ. Monoclonal Antibodies against EGFRvIII Are Tumor Specific and React with Breast and Lung Carcinomas and Malignant Gliomas. Cancer Res. 1995; $55: 3140-8$. 
10. Wikstrand CJ, McLendon RE, Friedman AH, Bigner DD. Cell Surface Localization and Density of the Tumorassociated Variant of the Epidermal Growth Factor Receptor, EGFRvIII. Cancer Res. 1997; 57:4130-40.

11. Roovers RC, Laeremans T, Huang L, De Taeye S, Verkleij AJ, Revets H, de Haard HJ, van Bergen en Henegouwen PM. Efficient inhibition of EGFR signalling and of tumour growth by antagonistic anti-EGFR Nanobodies. Cancer Immunol Immunother. 2007; 56:303-17.

12. Hamers-Casterman $\mathrm{C}$, Atarhouch $\mathrm{T}$, Muyldermans $\mathrm{S}$, Robinson G, Hamers C, Songa EB, Bendahman N, Hamers R. Naturally occurring antibodies devoid of light chains. Nature. 1993; 363:446-8.

13. Saerens D, Conrath K, Govaert J, Muyldermans S. Disulfide bond introduction for general stabilization of immunoglobulin heavy-chain variable domains. J Mol Biol. 2008; 377:478-88.

14. Dolk E, van Vliet C, Perez JM, Vriend G, Darbon H, Ferrat G, Cambillau C, Frenken LG, Verrips T. Induced refolding of a temperature denatured llama heavy-chain antibody fragment by its antigen. Proteins.2005; 59:555-64.

15. Ryckaert S, Pardon E, Steyaert J, Callewaert N. Isolation of antigen-binding camelid heavy chain antibody fragments (nanobodies) from an immune library displayed on the surface of Pichiapastoris. J Biotechnol. 2010; 145:93-8.

16. Muyldermans S. Single domain camel antibodies: current status. J Biotechnol. 2001; 74:277.

17. Vincke C, Loris R, Saerens D, Martinez-Rodriguez S, Muyldermans S, Conrath K. General strategy to humanize a camelid single-domain antibody and identifcation of a universal humanized Nanobody scaffold. J Biol Chem. 2009; 284:3273-84.

18. Kijanka M, Warnders FJ, El Khattabi M, Lub-de Hooge M, van Dam GM, Ntziachristos V, de Vries L, Oliveira S, van Bergen En Henegouwen PM. Rapid optical imaging of human breast tumour xenografts using anti-HER2 VHHs site-directly conjugated to IRDye $800 \mathrm{CW}$ for image-guided surgery. Eur J Nucl Med Mol Imaging. 2013; 40:1718-29.

19. Van de Broek B, Devoogdt N, D'Hollander A, Gijs HL, Jans K, Lagae L, Muyldermans S, Maes G, Borghs G. Specifc cell targeting with Nanobody conjugated branched gold nanoparticles for photothermal therapy. ACS Nano. 2011; 5:4319-28.

20. Behdani M, Zeinali S, Khanahmad H, Karimipour M, Asadzadeh N, Azadmanesh K, Khabiri A, Schoonooghe S, Habibi Anbouhi M, Hassanzadeh-Ghassabeh G, Muyldermans S. Generation and characterization of a functional Nanobody against the vascular endothelial growth factor receptor-2; angiogenesis cell receptor. Mol Immunol. 2012; 50:35-41.

21. Slørdahl TS, Denayer T, Moen SH, Standal T, Børset M, Ververken C, Rø TB. Anti-c-MET Nanobody ${ }^{\mathbb{R}}-\mathrm{a}$ new potential drug in multiple myeloma treatment. Eur J Haematol. 2013; 91:399-410.
22. Sadeqzadeh E, Rahbarizadeh F, Ahmadvand D, Rasaee MJ, Parhamifar L, Moghimi SM. Combined MUC1-specifc nanobody-tagged PEG-polyethylenimine polyplex targeting And transcriptional targeting of tBid transgene for directed killing of MUC1 over-expressing tumour cells. J Control Release. 2011; 156:85-91.

23. Cortez-Retamozo V, Backmann N, Senter PD, Wernery U, DeBaetselier P, Muyldermans S, Revets H. Efficient cancer therapy with a nanobody-based conjugate. N Biotechnol. 2004; 64:2853-7.

24. Behdani M, Zeinali S, Karimipour M, Khanahmad H, Schoonooghe S, Aslemarz A, Seyed N, Moazami-Godarzi R, Baniahmad F, Habibi-Anbouhi M, Hassanzadeh-Ghassabeh G, Muyldermans S. Development of VEGFR2-specifc Nanobody Pseudomonas exotoxin A conjugated to provide effcient inhibition of tumor cell growth. New biotechnology. 2013; 30:205-9.

25. Altintas I, Heukers R, van der Meel R, Lacombe M, Amidi M, van Bergen En Henegouwen PM, Hennink WE, Schiffelers RM, Kok RJ. Nanobody-albumin nanoparticles (NANAPs) for the delivery of a multikinase inhibitor 17864 to EGFR overexpressing tumor cells. J Control Release. 2013; 165:110-8.

26. Heukers R, Altintas I, Raghoenath $\mathrm{S}$, De Zan E, Pepermans R, Roovers RC, Haselberg R, Hennink WE, Schiffelers RM, Kok RJ, van Bergen en Henegouwen PM. Targeting hepatocyte growth factor receptor (Met) positive tumor cells using internalizing nanobody-decorated albumin nanoparticles. Biomaterials. 2014; 35:601-10.

27. Madhumathi J, Verma RS. Therapeutic targets and recent advances in protein immunotoxins. Curr Opin Microbiol. 2012; 15:300-9.

28. Antignani A, Fitzgerald D. Immunotoxins: The role of the toxin. Toxins. 2013; 5:1486-1502.

29. Presta L. Antibody engineering for therapeutics. Curr Opin Struct Biol. 2003; 13:519-525.

30. Selbo PK, Sivam G, Fodstad O, Sandvig K, Berg K. Photochemical internalisation increases the cytotoxic effect of the immunotoxin MOC31-gelonin. Int J Cancer. 2000; 87:853-9.

31. Chen M, Ye X, Cai J, Lin Y. Crystallization and preliminary crystallographic study of cucurmosin, a ribosomeinactivating protein from the sarcocarp of cucurbitamoschata. Acta Crystallogr D Biol Crystallogr. 2000; 56:665-6.

32. Shi X, Zhou E, Ye X, Meehan EJ, Chen M, Chen L. Molecular replacement researches of cucurmosin from Cucurbitamoschata: structure homology with trichosanthin. Chinese J Struct Chem. 2003; 22:165-8.

33. Chen M, Ye X. Ribosome-inactivating proteins: Cucurmosin. China Patent 99102290.4; 2000.

34. Chen M, Ye X. A peptide: A polypeptide with N-terminal sequence of cucurmosin. China Patent 03135045.3; 2003.

35. Chen M, Xie J, Xu Y, Hou X. Cucurmosin and its encodinggene. China Patent 200710008402.6; 2007. 
36. Hou X, Meehan EJ, Xie J, Huang M, Chen M, Chen L. Atomic resolution structure of cucurmosin, a novel type 1 ribosome- inactivating protein from the sarcocarp of Cucurbita moschata. J Struct Biol. 2008; 164:81-7.

37. Schmitz KR, Bagchi A, Roovers RC, van Bergen en Henegouwen PM, Ferguson KM. Structural evaluation of EGFR inhibition mechanisms for nanobodies VHH domains. Structure. 2013; 21:1214-24.

38. Roovers RC, Vosjan MJ, Laeremans T, el Khoulati R, de Bruin RC, Ferguson KM, Verkleij AJ, van Dongen GA, van Bergen en Henegouwen PM. A bi-paratopic anti-EGFR nanobody efficiently inhibits solid tumour growth. Int $\mathrm{J}$ Cancer. 2011; 129:2013-24.

39. Simon N, FitzGerald D. Immunotoxin Therapies for the Treatment of Epidermal Growth Factor Receptor-Dependent Cancers. Toxins. 2016; 8:E137.

40. Boskovitz A, Wikstrand CJ, Kuan CT, Zalutsky MR, Reardon DA, Bigner DD. Monoclonal antibodies for brain tumour treatment. Expert Opin Biol Ther. 2004; 4:1453-71.

41. Laskin JJ, Sandler AB. Epidermal growth factor receptor: a promising target in solid tumours. Cancer Treat Rev. 2004; 30:1-17.

42. Fish-Steagall A, Searcy P, Sipples R .Clinical experience with anti-EGFR therapy. Semin Oncol Nurs. 2006; 22:10-9.

43. Karamouzis MV, Grandis JR, Argiris A. Therapies directed against epidermal growth factor receptor in aero digestive carcinomas. JAMA. 2007; 298:70-82.

44. Kijanka M, Dorresteijn B, Oliveira S, van Bergen en Henegouwen PM. Nanobody-based cancer therapy of solid tumors. Nanomedicine (Lond). 2015; 10:161-74.

45. Genentech Inc. KadcylaTM (ado-trastuzumab emtansine): US prescribing information. 2013. https://www.accessdata. fda.gov/drugsatfda_docs/nda/2013/125427orig1s000crossr. pdf. Accessed 2014.

46. Genentech. FDA approves Genentech's Kadcyla (adotrastuzumab emtansine), the first antibody-drug conjugate for treating HER2-positive metastatic breast cancer [media release]. 2013.

47. Martinelli E, De Palma R, Orditura M, De Vita F, Ciardiello F. Anti-epidermal growth factor receptor monoclonal antibodies in cancer therapy. Clin Exp Immunol. 2009; 58:1-9.

48. Mok TS, Wu YL, Thongprasert S, Yang CH, Chu DT, Saijo N, Sunpaweravong P, Han, Margono B, Ichinose Y, Nishiwaki Y, Ohe Y, Yang JJ, et al. Gefitinib or CarboplatinPaclitaxel in Pulmonary Adenocarcinoma. N Engl J. Med. 2009; 361:947-57.

49. Shepherd FA, Rodrigues Pereira J, Ciuleanu T, Tan EH, Hirsh V, Thongprasert S, Campos D, Maoleekoonpiroj S, Smylie M, Martins R, van Kooten M, Dediu M, Findlay B, et al. Erlotinib in Previously Treated Non-Small-Cell Lung Cancer. N Engl J Med. 2005; 353:123-32.

50. Moore MJ, Goldstein D, Hamm J, Figer A, Hecht JR, Gallinger S, Au HJ, Murawa P, Walde D, Wolff RA,
Campos D, Lim R, Ding $K$, et al. Erlotinib Plus Gemcitabine Compared With Gemcitabine Alone in Patients With Advanced Pancreatic Cancer: A Phase III Trial of the National Cancer Institute of Canada Clinical Trials Group. J Clin Oncol. 2007; 25:1960-6.

51. Geyer CE, Forster J, Lindquist D, Chan S, Romieu CG, Pienkowski T, Jaqiello-Gruszfeld A, Crown J, Chan A, Kaufman B, Skarlos D, Campone M, Davidson N, et al. Lapatinib plus Capecitabine for HER2-Positive Advanced Breast Cancer. N Engl J Med. 2006; 355:2733-43.

52. Bianco R, Damiano V, Gelardi T, Daniele G, Ciardiello F, Tortora G. Rational combination of targeted therapies as a strategy to overcome the mechanisms of resistance to inhibitors of EGFR signaling. Curr Pharm Des. 2007; 13:3358-67.

53. Kolch W, Calder M, Gilbert D. When kinases meet mathematics: the systems biology of MAPK signalling. FEBS Lett. 2005; 579:1891-5.

54. Gille J, Swerlick RA, Caughman SW. Transforming growth factor alpha-induced transcriptional activation of the vascular permeability factor (VPF/VEGF) gene requires AP-2- dependent DNA binding and transactivation. EMBO J. 1997; 16:750-9.

55. Chandramohan V, Bigner DD. A novel recombinant immunotoxin-based therapy targeting wild-type and mutant EGFR improves survival in murine models of glioblastoma. Oncoimmunology. 2013; 2:e26852.

56. Endo Y, Mitsui K, Motizuki M, Tsurugi K. The mechanism of action of ricin and related toxic lectins on eukaryotic ribosomes. The site and the characteristics of the modification in $28 \mathrm{~S}$ ribosomal RNA caused by the toxins. J Biol Chem. 1987; 262:5908-12.

57. Sandvig K, van Deurs B. Delivery into cells: Lessons learned from plant and bacterial toxins. Gene Ther. 2005; 12:865-72.

58. Hamers-Casterman C, Atarhouch T, Muyldermans S, Robinson G, Hamers C, Songa EB, Bendahman N, Hamers R. Naturally occurring antibodies devoid of light chains. Nature. 1993; 363:446-8.

59. Xie J, Wang C, Yang A, Zhang B, Yin Q, Huang H, Chen M. Cucurmosin Kills Human Pancreatic Cancer SW-1990 Cells in vitro and in vivo. Anti-Cancer Agents in Medicinal Chemistry. 2013; 13:952-6.

60. Engebraaten O, Sivam G, Juell S, Fodstad O. Systemic immunotoxin treatment inhibits formation of human breast cancer metastasis and tumor growth in nude rats. Int $\mathrm{J}$ Cancer. 2000; 88:970-6.

61. Kreitman R, Pastan I. Recombinant single-chain immunotoxins against T- and B-cell leukemias. Leuk Lymphoma. 1994; 13:1-10.

62. Kreitman RJ, Pastan I. Importance of the glutamate residue of KDEL in increasing the cytotoxicity of Pseudomonas exotoxin derivatives and for increased binding to the KDEL receptor. Biochem J. 1995; 307:29-37. 
63. Kreitman RJ, Pastan I. Increased antitumor activity of circularly permuted interleukin 4-toxin in mice with interleukin 4 receptor-bearing human carcinoma. Cancer Res. 1995; 55:3357-63.

64. Kreitman RJ. Immunotoxins. Expert Opin Pharmacother. 2000; 1:1117-29.

65. Niesen J, Stein C, Brehm H, Hehmann-Titt G, Fendel R, Melmer G, Fischer R, Barth S. Novel EGFR specifc immunotoxins based on panitumumab and cetuximab show in vitro and ex vivo activity against different tumor entities. J Cancer Res Clin Oncol. 2015; 141:2079-95.

66. Wu S, Xie J. The preparation of immunotoxin C-CUS245C and detection of its anti-colorectal cancer activity in vitro and in vivo. Master Thesis. Fujian Medical University. 2016.

67. Lin J, Fu M, Xu C, Xie J. Preparation and Identification of the Immunotoxin Trastuzumab-Cucurmosin. Strait Pharmaceutical Journal. 2015; 5:239-42.

68. Dillon RL, Chooniedass S, Premsukh A, Adams GP, Entwistle J, MacDonald GC, Cizeau J. TrastuzumabdeBouganin Conjugate Overcomes Multiple Mechanisms of T-DM1 Drug Resistance. J Immunother. 2016; 39:117-26.
69. Selbo PK, Sivam G, Fodstad O, Sandvig K, Berg K. Photochemical internalisation increases the cytotoxic effect of the immunotoxin MOC31-gelonin. Int J Cancer. 2000; 87:853-9.

70. Vallera DA, Todhunter DA, Kuroki DW, Shu Y, Sicheneder A, Chen H. A bispecifc recombinant immunotoxin, DT2219, targeting human CD19 and CD22 receptors in a mouse xenograft model of B-cell leukemia/ lymphoma. Clin Cancer Res. 2005; 11:3879-88.

71. Stish BJ, Chen H, Shu Y, Panoskaltsis-Mortari A, Vallera DA. Increasing anticarcinoma activity of an antierbB2 recombinant immunotoxin by the addition of an antiEpCAM sFv. Clin Cancer Res. 2007; 13:3058-67.

72. Tang J, Li J, Zhu X, Yu Y, Chen D, Yuan L, Gu Z, Zhang X, Qi L, Gong Z, Jiang P, Yu J, Meng H, et al. Novel CD7specifc nanobody based immunotoxins potently enhanced apoptosis of CD7-positive malignant cells. Oncotarget. 2016; 7:34070-83. doi: 10.18632/oncotarget.8710.

73. Skehan P, Storeng R, Scudiero D, Monks A, McMahon J, Vistica D, Warren JT, Bokesch H, Kenney S, Boyd MR. New Colorimetric Cytotoxicity Assay for Anticancer-Drug Screening. J Natl Cancer Inst. 1990; 82:1107-12. 